A pan-European law on how data could be sourced, stored and used would, in theory, be good for research. Greater harmonization could smooth the difficulties that scientists face when they try to pool analysis of genomic data and tissue samples across national borders. Such sharing could help to organize powerful trials with large numbers of participants. But it is held back at present because different European countries have their own rules on issues such as informed consent, or on how to anonymize or pseudonymize data.

Unfortunately, as a result of their reworking, the draft rules threaten to place further restrictions on such studies, by tightening the way that samples and data can be used. The situation is so perilous that researchers met in Brussels last week for a 'Day of Action on Data for Health and Science', to explain to policy-makers "the reasons why personal data is necessary to scientific research, including medical research".

The reasons might sound obvious to scientists, and the need to explain them to politicians may seem distressing. But this is no antiscience agenda at play here. No one had intended to make medical research more difficult. The trouble is that such research is only a small part of the legislative issue. And discussions all take place in ministries of justice and other places where grasp of the mysterious world of science is relatively weak.

There is hope, in other words, that the feared damage can be avoided when the draft rules are finalized, possibly by the end of this year, as long as enough people make enough fuss to attract enough attention. To their credit, science funders and lobby groups across Europe have been doing just that.

The regulations proposed in 2012 by the commission allow the use of personal data only after an individual has given "specific, informed and explicit" consent. It is, after all, directed primarily at potential misuse of data gathered at websites or apps such as Facebook. But it made exceptions for health research because it recognized that such work depends on broad models of consent in which participants can agree for their data to be used in a variety of research studies, and that - subject to suitable safeguards - the data can be stored for future use.

Parliamentary amendments agreed last year changed the emphasis, and in doing so removed the exemption for research. If accepted, the amendments would require consent from participants for each
"The 'big data' eraposes new challenges, to privacy for example." new study. That would impede research. It is something that patient groups say they do not want if they donate data or tissue to a trusted party, such as established biobanks. And the evidence suggests that participants are less likely to give re-consent the more frequently they are asked for it.

Talks on the draft rules were due to restart this week, with trialogue negotiations scheduled between the European Commission, Parliament and Council. The council, at least, seems to be aware of the unwitting threat to research and wants to do something about it. Its statement on the issue, published last week, indicates that it will argue for the research exemption to be maintained.

Why should science be seen as a special case? A rigorous governance and regulatory framework for biomedical research already exists and operates under national and international laws. As this journal has chronicled, the 'big data' era poses new challenges, to privacy for example. But from a scientific standpoint, it makes more sense to update these existing rules as required than for valuable research to be threatened by overarching laws aimed at a different problem.

The European data-protection drive is built on the principle of "one continent, one law, one regulation". But even the most committed believers may have to accept that biomedical research must remain an exception - and be granted an exemption - if it is to continue to thrive.

\section{Life under the ice}

\section{Antarctica's apparent barrenness hides an abundance of living organisms.}

$\mathrm{M}$ any of our views of the continent of Antarctica are influenced by the words of the great polar explorers. Robert Falcon Scott, a man ultimately drawn to his death there, famously wrote of the Antarctic, "Great God, this is an awful place". Present-day adventurers, from those who follow in the footsteps of Scott to the interior to tourists skirting around the edge, also trade on the sheer other-worldliness of Earth's southern cap. The more remote Antarctica is, the more their sense of achievement. Head there by ship and - if you can stand the swell - you can peer over the side to watch the seawater change colour at the convergence point where cold currents circling the continent push up against the warmer waters of the southern Pacific Ocean.

To stand on Antarctica is truly like nothing else on Earth. On a still day, it is as if time itself has frozen. Senses, the essential guides to life on our planet, are almost redundant. There is no movement, no sound and no smell. Scientists who spend time there have been known to take curry powder on their field expeditions, to prepare spicy food to compensate for the lack of other stimulation. With centuries-old snow beneath your feet and only the occasional rumble of distant ice cliffs collapsing into the ocean, it is easy to imagine Antarctica - and those who spend time there - as isolated from the rest of the world and its life.

Look in a different direction, however, and the illusion fades. Scott knew this. "As one looks across the barren stretches of the pack, it is sometimes difficult to realise what teeming life exists immediately beneath its surface," he wrote. "Beneath the placid ice floes and under the calm water pools the old universal warfare is raging incessantly in the struggle for existence." There is life in Antarctica; you just need to know where to look.

For a sense of the teeming life that exists in the white continent, take a look at the Review article that we publish this week on page 431. Yes, there are only two species of flowering plants in Antarctica, but nobody said that the place had to look pretty. Think small. More than 200 species of lichen and 100 species of moss cling to the coastline and to patches of exposed rock. The packed snow that rests on the Antarctic bedrock is riddled with water-filled holes, and these subglacial lakes support the highest diversity of viruses of any known aquatic system.

Still not impressed? Head offshore - not too far - and the Antarctic waters thrive with so much life that they are considered to harbour more biodiversity than the celebrated Galapagos Islands. Throughout the Southern Ocean, researchers have discovered more than 8,000 marine species, most of which scrape a living from the seabed. From such a rich base, a network of life spreads upwards and outwards until it culminates in the region's iconic seals, penguins, whales and albatrosses.

The point of this continental audit is threefold. Antarctica is alive - and therefore dynamic. Some change is bad and some good, but most points in the same direction: that Antarctica's isolation from the rest of the world - biological, physical and cultural - is weakening. And in a world that increasingly looks to value from the $\rightarrow$ NATURE.COM To comment online, click on Editorials at: go.nature.com/xhunqv natural environment, the Review article sums up the place nicely. "Antarctic ecosystems provide several services essential to planetary stability." Awful or not, Antarctica is closer to home than many realize. 